\title{
MEASUREMENT OF OUTFLOW FROM A SNOWBANK WITH BASAL ICE
}

\author{
By Kathy L. Young and Antoni G. Lewkowicz
}

(Department of Geography, Erindale College, University of Toronto,

Mississauga, Ontario L5L 1C6, Canada)

ABSTRACT. A technique is described for measuring melt-water outflow from snowbanks that develop a basal ice layer. The method involves excavation of channels across ice exposed at the lower edge of a snowbank in order to divert run-off into a portable flume. Since discharges are measured before the water comes into contact with the soil, sub-surface flow and soil-moisture changes do not have to be assessed. Outflow discharges recorded at a perennial snowbank site on Melville Island, N.W.T., Canada, compare favourably with energy-balance calculations and measurements of ablation.

\section{INTRODUCTION}

Snow melt is regarded as the most significant hydrological input to non-glacierized basins in alpine (e.g. Jordan, 1983), sub-Arctic (e.g. Dunne and others, 1976), Low Arctic (e.g. Landals and Gill, 1973; Onesti and Walti, 1983), and High Arctic environments (e.g. Lewkowicz and French, 1982; Woo, 1983; Woo and others, 1983). Consequently, a thorough understanding of the relationship between snow melt and stream run-off is essential for many aspects of resource development in these regions (Walker and Lake, 1973; Colbeck, 1977).

The two main approaches used to determine run-off resulting from snow melt are modelling and direct measurement. Vertical and horizontal movements of melt water in homogeneous and layered snow-packs have been modelled extensively (e.g. Colbeck, 1971, 1972, 1973, 1974, 1977) and flow equations have been tested in alpine areas (e.g. Jordan, 1979) and in the sub-Arctic (Dunne and others, 1976; Price, 1977). More recently, a simulation model has been developed which describes water movement through flow fingers, the growth of ice lenses and wetting-front advance in High Arctic snow-packs (Marsh and Woo, 1984b). It also predicts basal ice growth and run-off. In spite of these advances, more work is required before models can accurately describe melt-water movement and quantify run-off for snowbanks which are both non-uniform in depth and heterogeneous in structure. Field measurements of run-off from snow will continue to be necessary for the development and verification of such models.

Direct measurement of snow melt and run-off in northern areas has relied mainly on instrumented hill-slope plots. A review of researchers and their methods has been presented by Steer and Woo (1983). In most studies, run-off was measured on the ground surface down-slope of the snow. This increases the potential for error in estimating snow melt, since evapotranspiration, sub-surface flow, and ground-storage changes all have to be considered (e.g. Dunne and Black, 1971; Dunne and others, 1976; Lewkowicz and French, 1982; Steer and Woo, 1983).

This paper describes a technique for the direct measurement of outflow from snow that has developed a basal ice layer. The method can be used in snow of heterogeneous depth and structure, and reduces the possibility of error in assessing melt since discharges are measured before the water comes into contact with the substrate. The technique could be employed to provide observed outflow values for comparison with predictions from snow-melt models, to determine snow-melt inputs to experimental plots or to a drainage basin, or to estimate the energy balance of ablating snow. The method was tested at the site of a perennial snowbank on south-east Melville Island, Northwest Territories, Canada (Figs 1 and 2), in July and August 1986. The discharge data obtained compare favourably with independent measurements of the energy balance and snow ablation.

\section{METHOD}

The method can be used to monitor outflow from any snowbank that possesses a basal ice layer. Basal ice develops when negative ground temperatures are present beneath a melting snow-pack and a sufficiently large soil thermal gradient exists for latent heat released by freezing to be conducted into the substrate (Woo and Heron, 1981; Woo and others, 1982). The basal ice layer has a low permeability and once formed beneath a snow-pack is usually effective in preventing subsequent melt waves from

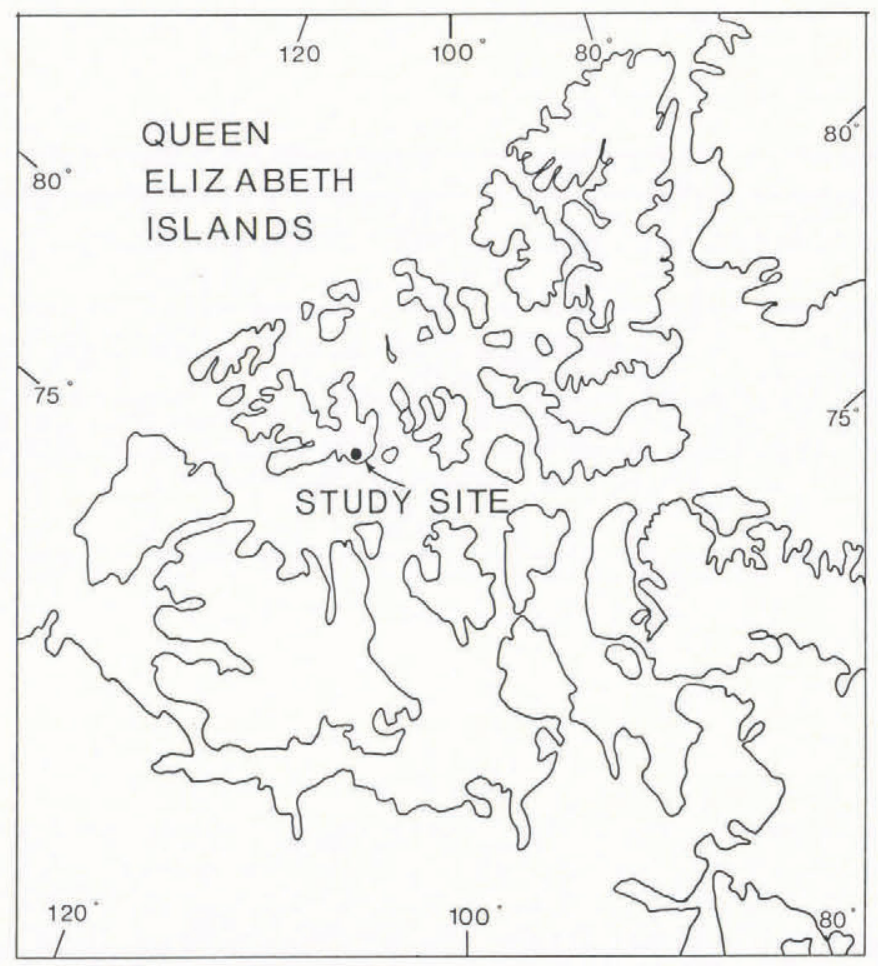

Fig. 1. Location of the study site, south-east Melville Island, N.W.T., Canada. 

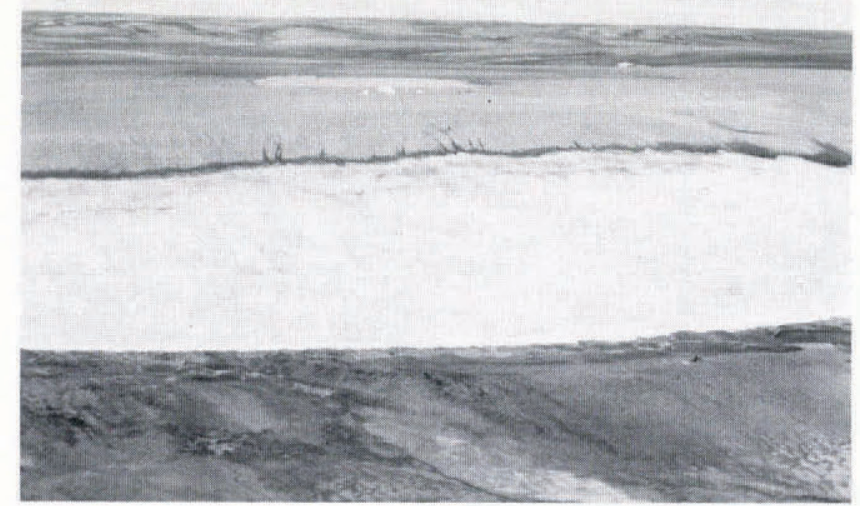

Fig. 2. Photograph of the perennial snowbank at Ross Point (lat. $74^{\circ} 57^{\prime}$ N., long. $107^{\circ} 19^{\prime}$ W.). 7 July 1986. Note tents at the bottom of the snowbank (right) and in the background for scale.

infiltrating into the soil. Basal ice is a widespread phenomenon (Marsh and Woo, 1984a) and has been observed in High Arctic, sub-Arctic, and alpine environments.

The equipment to be used in the field is set up at the down-slope edge of the ablating snow (Fig. 3). Each set consists of a splash disperser, collection tray, large-diameter hose (dryer-type), and a portable trapezoidal flume with stilling well. The flume used can measure a flow range of $0.07-4.31 / \mathrm{s}$ but flumes of similar design are available for higher or lower discharge ranges (Bos and others, 1984, p. 148-58). A potentiometric water-level recorder measures stage within the stilling well and output is recorded on a data logger (Campbell Scientific CR21) to an accuracy of $\pm 0.6 \mathrm{~mm}$. Stage records in millimeters can be converted into discharges using published rating curves which have errors of less than 2\% (Bos and others, 1984). Additional pieces of equipment include an ice-axe to excavate channels in the

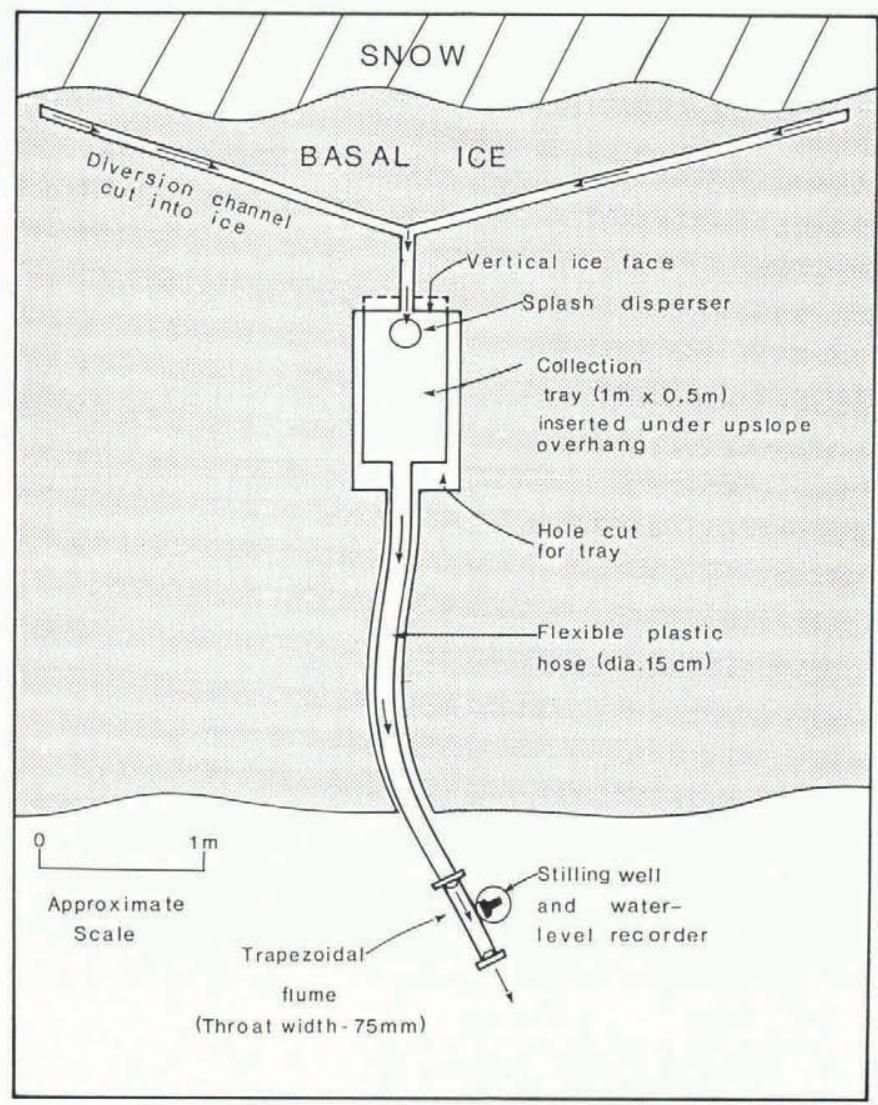

Fig. 3. Dimensions and general lay-out of the apparatus (plan view).

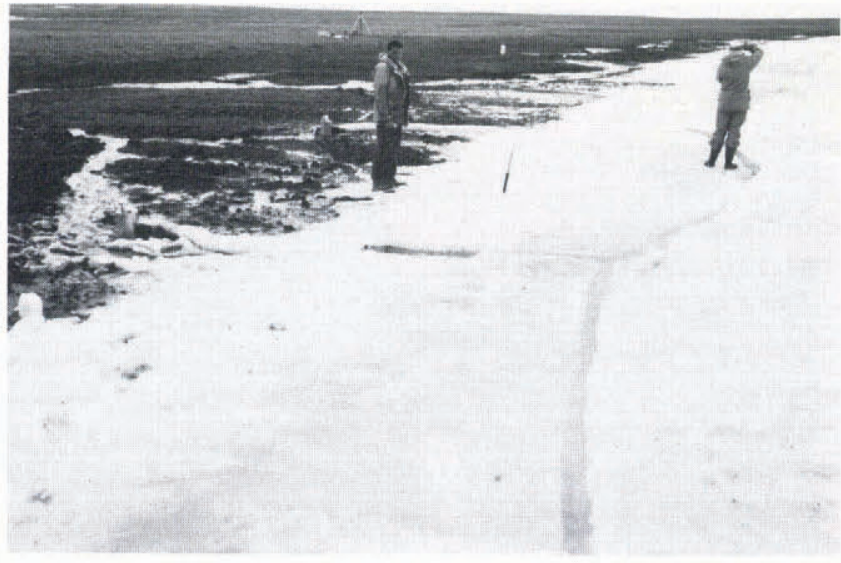

Fig. 4. Photograph of excavation of diversionary channels in basal ice at the bottom of the snowbank. Snow was cleared off the basal ice down-slope of the channels but remains on the up-slope side.

basal ice and install the collection tray, and a builder's level to ensure that the flume remains horizontal.

In the field experiments, two flumes were used side by side. The size of their collection areas was dictated by the natural contours of the slope. Rhodamine dye was employed to locate the collection system prior to mounting the flumes. Dye samples were spaced at $5 \mathrm{~m}$ intervals across basal ice exposed at the top edge of the snowbank and they surfaced some hours later at the bottom edge. Y-shaped channels $5-10 \mathrm{~cm}$ wide and of similar depth were excavated in the basal ice at the locations of dye emergence (Fig. 4). The arms of each Y extended across the slope for three dye traces and, depending on the degree of flow convergence, this was a distance of $7-10 \mathrm{~m}$. The central stem leading down-slope was generally $1-2 \mathrm{~m}$ long. The channels were cut so that all water draining down-slope over the basal ice layer was diverted into the central stem channel. At the end of the latter, a hole up to $50 \mathrm{~cm}$ deep was excavated for the collection tray. The up-slope face of this hole was undercut by about $10 \mathrm{~cm}$ so that water flowing or dripping from the central stem channel down the face was caught by the upper part of the tray. A splash disperser, consisting of a metal ring with notches cut in its lower end, was used beneath the main flow from the stem channel to reduce water losses from the tray. The down-slope exit of the collection tray led into a hose set in a channel in the basal ice, and this was connected to a portable flume which was mounted on the ground down-slope of the snowbank (Figs 5 and 6).

A fairly rigorous schedule of maintenance of the apparatus was required to minimize losses of water from the system. The channels in the ice were deepened every few hours during the day and less frequently at night to ensure that their floors were in hard, nearly impermeable basal ice and not in the more porous surface ice layer which

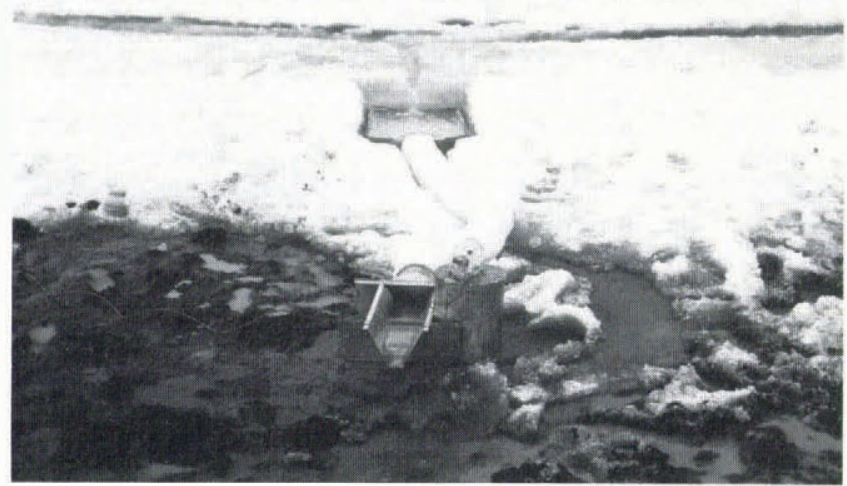

Fig. 5. Photograph showing a view up-slope of the diversionary channels, collection tray, and flume. Note that the splash disperser is not in place on the tray. 


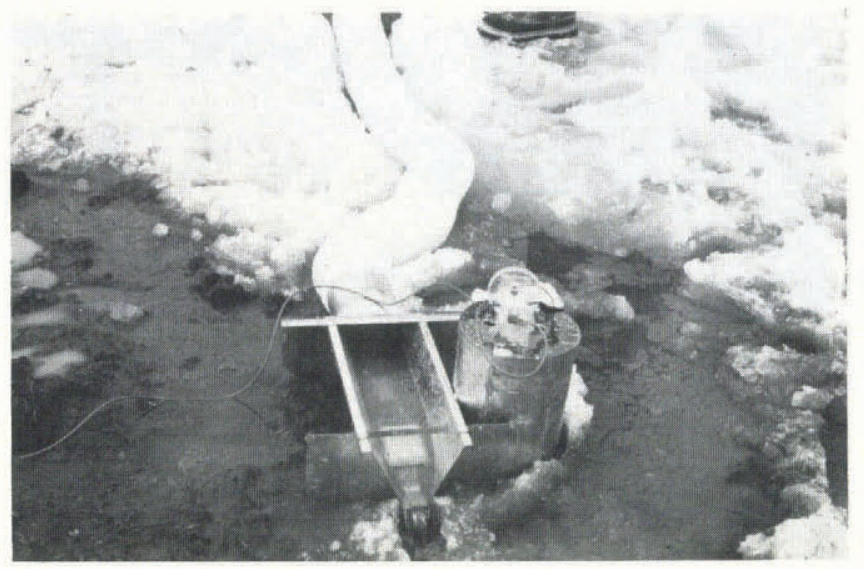

Fig. 6. Photograph of the flume and stilling well in operation.

developed during ablation. This was confirmed by injecting dye into the channels and observing that it entered the central stem and did not diffuse into the ice down-slope. In addition, the ice face overhanging the collection tray was cut back about twice a day to prevent water from trickling down the face and dripping to the rear of the tray. A large piece of cardboard was used to shield the ice face from direct solar radiation. Because the flumes were mounted on thawing ground, they had to be checked regularly to ensure that they remained horizontal. A consequence of the maintenance schedule is that it would require some effort to obtain continuous outflow records. In the present study, two people were able to operate the instrumentation successfully for four $3 \mathrm{~d}$ periods over 4 weeks, while simultaneously undertaking numerous other tasks.

\section{RESULTS}

The utility of the outflow measurement is illustrated by comparisons with the energy balance of the snowbank (Fig. 7) and with ablation measurements (Fig. 8). Monitoring of the former took place at three meteorological towers spaced in a line up the snowbank, each of which provided an estimate of sensible- and latent-heat exchanges, while at the central tower radiative exchanges were also measured. Readings of the various instruments (wet- and dry-bulb thermocouples, anemometers, and radiometers) took place at $10 \mathrm{~s}$ intervals with averages integrated over $30 \mathrm{~min}$ periods on two Campbell Scientific CR21 data loggers and one CR21X data logger. The values shown in Figure 7 represent the average energy balance for the complete transect of the snowbank. The best-fit regression line lies above the $1: 1$ line, indicating that, if the energy-balance figures are accurate, the flumes underestimated the true outflow discharges on average by about $6 \%$. The greatest potential for error in the discharge calculated from the energy balance lies in the estimate of the size of the sub-snow plot. It was assumed that the plot was essentially rectangular and that any convergence or divergence of flow indicated by the dye occurred at the base of the slope where the gradient declined. Moreover, a change in the sub-snow contributory area could have occurred after the initial determination using the dye tracers. These potential errors, combined with the possibility of minor losses of water during flow from the ice on to the collection tray, probably account both for the scatter in Figure 7 and the overall slight underestimate.

Ablation measurements were undertaken daily along a snow course consisting of 25-30 targets spaced at $5 \mathrm{~m}$ intervals up the snowbank. A Wild T1A theodolite was used to sight on the targets which were positioned on undisturbed snow alongside permanent markers immediately before the survey began. In addition, a Mount Rose snowsampling kit was used to establish snow densities for five to eight samples taken daily near the bottom edge of the snowbank. Comparison of the outflow and surface ablation (Fig. 8) required that an appropriate lag time be used and

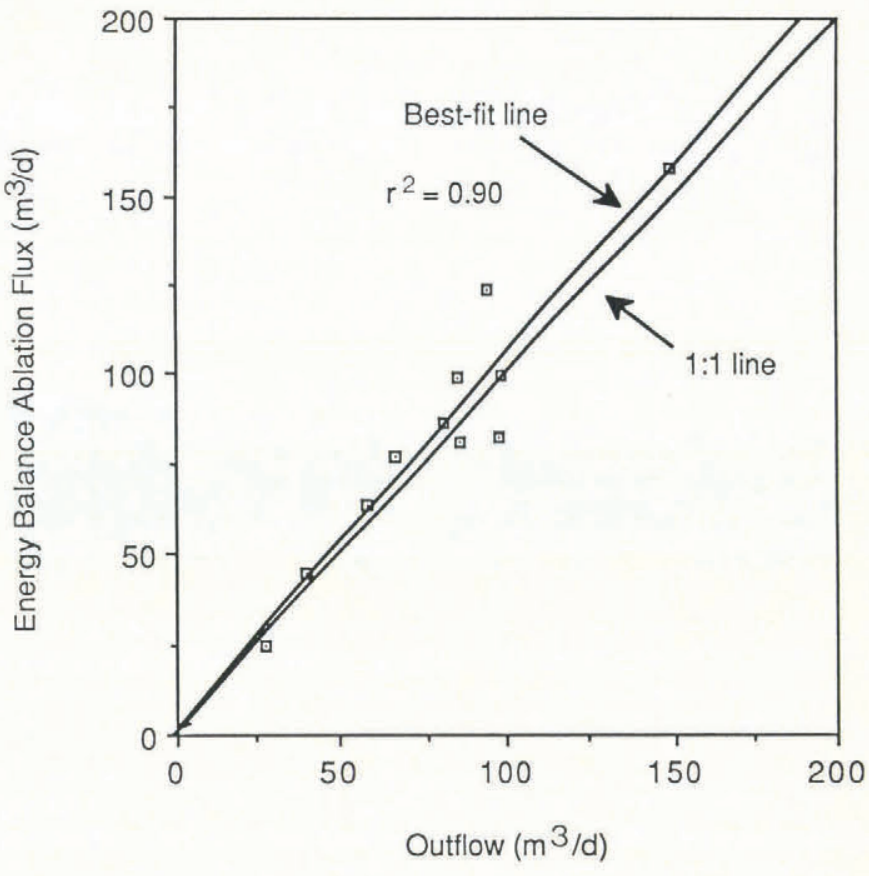

Fig. 7. Comparison of daily outflow discharges measured by the flumes and discharges calculated from energy-balance measurements. Note: diurnal discharge hydrographs separated by time-of-rise and compared to energy-balance measurements separated in the same manner. Best-fit line passes through the origin since initial regression produced a non-significant constant.

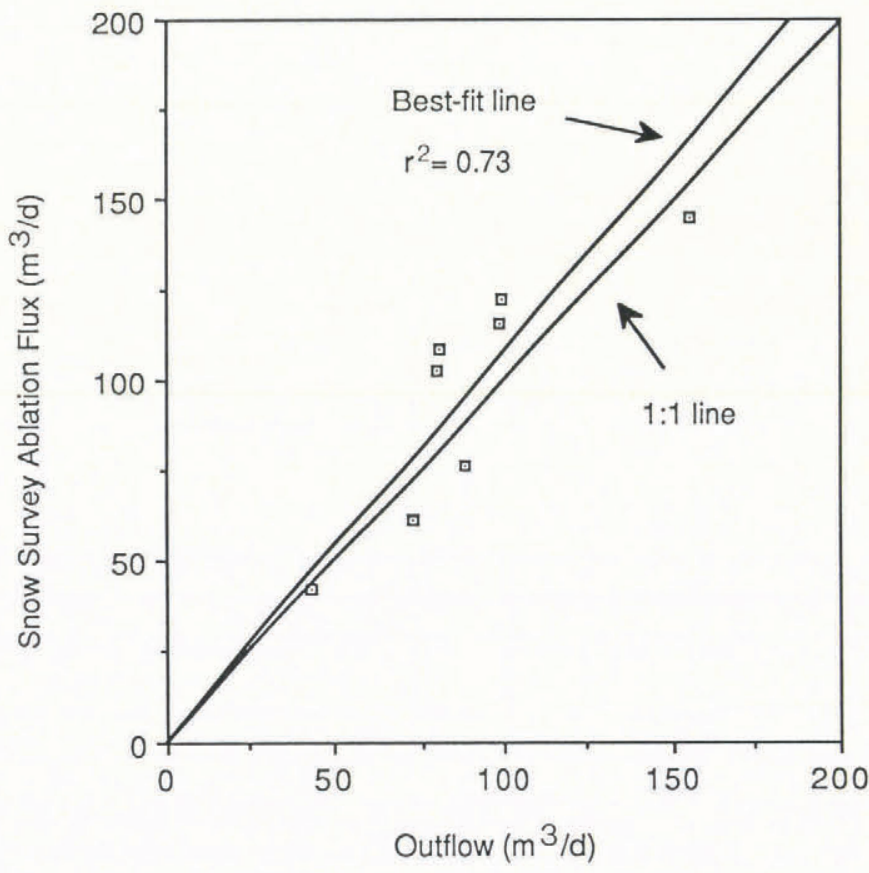

Fig. 8. Comparison of daily outflow discharges measured by the flumes and discharges calculated from ablation measurements. Note: diurnal discharge hydrographs separated relative to the timing of the ablation survey with lag times established from a comparison of energy-balance measurements and outflow discharges. Best-fit line passes through the origin since initial regression produced a nonsignificant constant.

this was established from the lag between peak energy inputs and peak outflow. The best-fit regression line in Figure 8 lies above the $1: 1$ line, indicating that, if ablation calculations are accurate, the flumes again underestimated the true outflow discharges on average by about $6 \%$. However, since snow-density meaurements were taken in only one part on the snowbank and snow tubes tend to 
overestimate water equivalents by $7-12 \%$ (Work and others, 1965), it is possible that, in addition to the potential errors described above, snow ablation itself may have been exaggerated.

An example of a typical outflow hydrograph from the permanent snowbank obtained, using the flumes, is shown in Figure 9 and compared with the surface-ablation flux derived from the energy-balance measurements. The

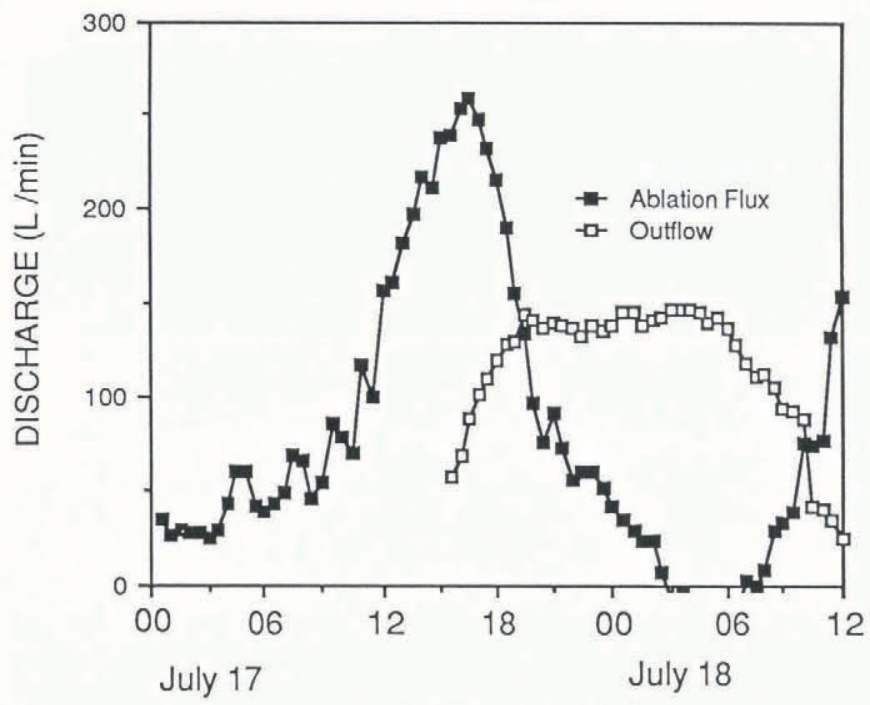

LOCAL TIME (h)

Fig. 9. Typical outflow hydrograph compared to surfaceablation flux, 17-18 July 1986.

hydrograph is composed of a moderately sloping rising limb, a plateau, and a more gently sloping falling limb. This shape differs from that obtained in other studies in the Arctic (e.g. Lewkowicz and French, 1982; Woo and Steer, 1982), and is attributed to three factors. First, a much greater depth of snow was present in the perennial snowbank than at most other study sites $(>4.5 \mathrm{~m}$ in places at the end of winter). Deep snow produces surface hydrographs which are characterized by flatter peaks and longer recessions than those originating from shallower snow-packs (e.g. Jordan, 1983). A second factor is the non-uniformity of snow depths at the perennial snowbank. The hydrograph shape appears to indicate that melt-water waves, originating simultaneously from the surface, arrived at different times at the base of the snow. Finally, the plateau appearance of the hydrograph suggests that water flow in the snowbank was planar. If convergence of flow had occurred, a more peaked response probably would have resulted. Because of the heterogeneity of the snow depths at this site, this hydrograph would be difficult to model successfully.

\section{CONCLUSIONS}

The method described measures discharges from snow-packs with continuous basal ice layers, without the outflow coming into contact with the substrate. Daily discharges obtained using the technique at the site of a perennial snowbank in the High Arctic compare favourably with independent measurements of energy exchange and surface ablation. The flexibility in the range of flows that can be measured by the flumes, the overall portability of the apparatus, and the moderate effort needed to construct the diversionary channels make this method suitable for monitoring snow-melt outflow in isolated northern areas. With appropriate modifications for mounting the flumes on rods set in the ice, the apparatus could also be used to monitor run-off from glacier surfaces.

\section{ACKNOWLEDGEMENTS}

This study was supported by funds from the Natural Sciences and Engineering Research Council of Canada (operating grant A2643 and northern supplement N0218 to AGL) and by a Northern Scientific Training Grant, Department of Indian Affairs and Northern Development, Canada (to KLY and AGL). Generous logistical support was provided through G.D. Hobson, Director, Polar Continental Shelf Project, Department of Energy, Mines and Resources, Canada (project $36-83$ to $\mathrm{AGL}$ ).

The authors are grateful for the unflagging field assistance of S.I. Hamilton and for helpful discussions with J.M.C. Lalonde during the design of the equipment. Construction of the trays and flumes was efficiently carried out by the staff of the Erindale College academic workshop, and we gratefully acknowledge this contribution. The suggested improvements to the manuscript of two anonymous referees are appreciated by adoption.

\section{REFERENCES}

Bos, M.G., J.A. Replogle, and A.J. Clemmens. 1984. Flow measuring flumes for open channel systems. New York, Wiley.

Colbeck, S.C. 1971. One dimensional water flow through snow. CRREL Res. Rep. 296.

Colbeck, S.C. 1972. A theory of water percolation in snow. J. Glaciol., 11(63), 369-385

Colbeck, S.C. 1973. Effects of stratigraphic layers on water flow through snow. CRREL Res. Rep. 311.

Colbeck, S.C. 1974. Water flow through snow overlying an impermeable boundary. Water Resour. Res., 10(1), 119-123.

Colbeck, S.C. 1977. Short-term forecasting of water run-off from snow and ice. J. Glaciol., 19(81), 571-588.

Dunne, T. and R.D. Black. 1971. Runoff processes during snowmelt. Water Resour. Res., 7(5), 1160-1172.

Dunne, T., A.G. Price, and S.C. Colbeck. 1976. The generation of runoff from subarctic snowpacks. Water Resour. Res., 12(4), 677-685.

Jordan, R.P. 1979. Response of an alpine watershed to snowmelt. In Associate Committee on Hydrology. Canadian Hydrology Symposium: 79-Cold Climate Hydrology. Proceedings. Ottawa, National Research Council of Canada, 323-333.

Jordan, R.P. 1983. Meltwater movement in a deep snowpack, 1. Field observations. Water Resour. Res., 19(4), 971-978.

Landals, A.L. and D. Gill. 1973. Differences in volume of surface runoff during the snowmelt period: Yellowknife, Northwest Territories. In The Role of Snow and Ice in Hydrology. Proceedings of the Banff symposia, September 1972. Vol. 2, 927-942.

Lewkowicz, A.G. and H.M. French. 1982. The hydrology of small runoff plots in an area of continuous permafrost, Banks Island, N.W.T. In French, H.M., ed. The Roger J.E. Brown memorial volume. Proceedings of the Fourth Canadian Permafrost Conference, Calgary, Alberta, March 2-6, 1981. Ottawa, National Research Council of Canada, $151-162$

Marsh, P. and M.-K. Woo. 1984a. Wetting front advance and freezing of meltwater within a snow cover, 1. Observations in the Canadian Arctic. Water Resour. Res., 20(12), 1855-1864.

Marsh, P. and M.-K. Woo. 1984b. Wetting front advance and freezing of meltwater within a snow cover, 2. A simulation model. Water Resour. Res., 20(12), 1865-1874.

Onesti, L.J. and S.A. Walti. 1983. Hydrologic characteristics of small Arctic-alpine watersheds, central Brooks Range, Alaska. Permafrost. Fourth International Conference. Proceedings. July 17-22, 1983, Fairbanks, Alaska. Washington, DC, National Academy Press, 957-961.

Price, A.G. 1977. Snowmelt runoff processes in a subarctic area. Montreal, McGill University. Department of Geography. (McGill Sub-Arct. Res. Pap. 29; Climatol. Res. Ser. 10.)

Steer, P. and M.-K. Woo. 1983. Measurement of slope runoff in a permafrost region. Can. Geotech. J., 20(2), 361-365.

Walker, E.R. and R.A. Lake. 1975. Runoff in the Canadian Arctic Archipelago. In Weller, G. and S.A. Bowling, eds. Climate of the Arctic. Fairbanks, AK, University of Alaska. Geophysical Institute, 374-378. 
Woo, M.-K. 1983. Hydrology of a drainage basin in the Canadian High Arctic. Ann. Assoc. Am. Geogr., 73, 577-596.

Woo, M.-K. and R. Heron. 1981. Occurrence of ice layers at the base of High Arctic snowpacks. Arct. Alp. Res., 13(2), 225-230.

Woo, M.-K. and P. Steer. 1982. Occurrence of surface flow on Arctic slopes, southwestern Cornwallis Island. Can. J. Earth Sci., 19(12), 2368-2377.

Woo, M.-K., R. Heron, and P. Marsh. 1982. Basal ice in
High Arctic snowpacks. Arct. Alp. Res., 14(3), 251-260. Woo, M.-K., P. Marsh, and P. Steer. 1983. Basin water balance in a continuous permafrost environment. Permafrost. Fourth International Conference. Proceedings. July 17-22, 1983, Fairbanks, Alaska. Washington, DC, National Academy Press, 1407-1411.

Work, R.A., H.J. Stockwell, T.G. Freeman, and R.T. Beaumont. 1965. Accuracy of field snow surveys, western United States, including Alaska. CRREL Tech. Rep. 163.

MS. received 29 December 1987 and in revised form 25 May 1988 